\title{
Effectiveness of the Hatam Language Booklet on Family Knowledge and Attitudes About TB on Children in Warmare District, Manokwari Regency
}

\author{
Ivonne Junita Fabanjo ${ }^{1}$, Yayuk Nuryanti ${ }^{1}$, Anwar Mallongi ${ }^{2}$ \\ ${ }^{1}$ Lecturers of Poltekkes Kemenkes Sorong, ${ }^{2}$ Professor of Environmental Health Department, \\ Faculty of Public Health, Hasanuddin University, Makassar
}

\begin{abstract}
Lack of public understanding regarding the symptoms of tuberculosis(TB) and its relevance to the risk of getting TB, makes TB cases difficult to detect in Indonesia. Increasing knowledge about TB is an important component of a TB control strategy. Patient and family knowledge will improve prevention behavior and medication adherence. One way to increase knowledge is through promotion or health education. The purpose of this study was to determine the effectiveness of the Hatam language booklet on family knowledge and attitudes about TB in children in Warmare District, Manokwari Regency, West Papua Province. This study used a Quasi Experiment design with Pre-Post test without control group involving 50 families with toddlers who live in Warmare district. Data were collected using a knowledge and attitude questionnaire given before and after education using the Hatam language booklet. Data analysis used the Wilcoxon test. Result, There is a significant difference which indicates that the mean score of knowledge and attitudes before and after the implementation of the Hatam Language Education Booklet has increased by 39.80 and family attitudes have increased by 6.98 , the $p$-value is $0.000(\mathrm{p}<0.05)$. in conclusion, Health education using booklets and a cultural approach effectively increase public knowledge and attitudes
\end{abstract}

Keywords: Language Booklet, Family Knowledge, Attitudes About TB.

\section{Introduction}

Tuberculosis (TB) is a contagious disease that is transmitted through the air and is one of the top ten causes of death ${ }^{12}$. The five countries that have the biggest burden of tuberculosis are India, Indonesia, China, the Philippines and Pakistan and there are also challenges that must be faced and become a concern, namely the increasing cases of MDR-TB, TB-HIV, TB with DM, $\mathrm{TB}$ in children and other vulnerable communities ${ }^{3}$.

WHO defines High Burden Countries (HBC) for TB based on three indicators, namely Tuberculosis, Tuberculosis with HIV, TB/MDR. There are 48 countries on the list. One country can be included in one of the lists or all three, Indonesia together with 13 countries, are included in the HBC Indicator for the three categories, which means that Indonesia is experiencing major problems and challenges in facing the TB problem ${ }^{6}$

In 2016 an estimated 67 million children with Latent $\mathrm{TB}$, and $70-80 \%$ suffer from pulmonary $\mathrm{TB}$, and the rest is extrapulmonary TB. Based on the WHO roadmap report to stop TB in children and adolescents in 2018 shows that an estimated 1 million children are infected with TB every year and 233,000 deaths of children aged $0-14$ years in $2017,80 \%$ of deaths occur in children under 5 years, $96 \%$ do not get treatment services ${ }^{4}$ and 25,000 children will develop into Multi Drug Resistant TB every year ${ }^{10}$.

In Indonesia, the proportion of TB cases in children who are notified based on the 2018 Indonesian health profile is $10.08 \%$, one of the TB problems in children in Indonesia is diagnosis, which has been implemented since 2005 as the TB scoring system as a diagnostic approach, which is a problem not all health facilities have Tuberculin Test and Thorax Photo facilities, these two indicators are contained in the scoring system, which cause underdiagnosis of TB in children, another problem is the increasing number of drug-resistant $\mathrm{TB}$ cases in adults which is a source of transmission for children 6,3 
Research conducted by Faradis and Indarjo on the implementation of Permenkes number 67 of 2016 policy for tuberculosis control shows that of the 4 indicators in policy implementation and there are 2 indicators that have not been optimally implemented, namely policy resources that have not been fully met and a lack of community support in TB control ${ }^{4}$. Increasing knowledge about TB is an important component of a TB control strategy. Patient and family knowledge will improve prevention behavior and medication adherence ${ }^{5}$. One way to increase knowledge is through promotion or health education. Health education can be delivered in various health media, both electronic and non-electronic, one of the media that is often used because it is interesting and simple is made in the form of a pocket book or booklet ${ }^{8}$.

Based on data from the Eradication and Prevention of Infectious Diseases, West Papua Province, the total number of TB cases treated and reported in 2018 was 2180 cases and especially in Manokwari district itself, amounting to 798 cases of which Warmare District is an area of Manokwari Regency.

\section{Materials and Method}

The research design used a Quasi Experiment with Pre-Post test without control Group which looked for the effectiveness or influence between variables, namely the Effectiveness of Hatam Language Booklets on Family Knowledge and Attitudes about TB in Children in Warmare District, Manokwari Regency, where knowledge and attitudes were measured before and after education was given. This research was conducted from October to November. Respondents were given a pretest questionnaire to assess knowledge of pulmonary tuberculosis. Then the intervention was carried out to provide education using hatam language booklet which was also given to the respondent and after being given the intervention, a measurement was carried out to determine the respondent's knowledge and attitude. The number of respondents involved in the study amounted to 50 people. Before the data analysis was carried out, the data normality test was carried out with the data normality test that will be used in this study is the SaphiroWilk test because the sample size was 50 respondents and the results of the data normality test showed $p$ value $<0.05$ so it can be concluded that the data distribution was not normal. differences in knowledge and attitudes before and after the intervention using the Wilcoxon Test.

\section{Results}

This study involved 50 respondents who are families who have children under five and there are family members who suffer from tuberculosis.

\section{a. Respondent Characteristics}

Table 1. Age Distribution of Respondents in Warmare District November 2019

\begin{tabular}{|l|c|c|c|c|}
\hline Variable & n & Mean & SD & (Min-Max) \\
\hline Respondents Age & 50 & 37,42 & 8,64 & $20-55$ \\
\hline
\end{tabular}

The mean age of the respondents was 37.42 years with an age variation of 8.64 years. The youngest age of the respondents was 20 years and the oldest was 55 years.

Table 2. Distribution of Gender and Occupation of Respondents in Warmare District November 2019

\begin{tabular}{|l|c|c|}
\hline Variable & $\mathbf{n}$ & $\mathbf{\%}$ \\
\hline Gender \\
\hline Male & 0 & 0 \\
\hline Female & 50 & 100 \\
\hline Total & 50 & 100 \\
\hline Pekerjaan \\
\hline Occupation & 7 & 14 \\
\hline No Occupation & 43 & 86 \\
\hline Total & $\mathbf{5 0}$ & $\mathbf{1 0 0}$ \\
\hline
\end{tabular}

$100 \%$ of respondents are female and those who have occupation are $7(14 \%)$ respondents and No occupation are $43(86 \%)$ of respondents.

Table 3. Distribution of Respondents Education in Warmare District November 2017

\begin{tabular}{|l|c|c|}
\hline Variable & n & \% \\
\hline Education & \multicolumn{2}{|l|}{} \\
\hline Basic & 37 & 74 \\
\hline Middle & 5 & 10 \\
\hline High & 8 & 16 \\
\hline Total & $\mathbf{5 0}$ & $\mathbf{1 0 0}$ \\
\hline
\end{tabular}

It shows that some respondents with basic education level were 37 people (37\%), Middle education was 5 people $(10 \%)$, higher education was 5 people $(16 \%)$. 
b. Knowledge and attitude before and after the implementation of Education the Hatam language booklet

Table 4. Analysis of Respondents' Knowledge and Attitudes Before the Implementation of the Hatam Language Booklet

\begin{tabular}{|l|c|c|c|}
\hline Variable & Mean & SD & Min-Max \\
\hline Knowledge & 50,80 & 14,18 & $30-80$ \\
\hline Attitudes & 26,94 & 22,00 & $22-32$ \\
\hline
\end{tabular}

Indicates that the mean score of knowledge before the implementation of education was 50.80 while the mean score for attitude was 26.94
Table 5. Analysis of Respondents' Knowledge and Attitudes After the Implementation of the Hatam Language Booklet

\begin{tabular}{|l|c|c|c|}
\hline Variabel & Mean & SD & Min-Max \\
\hline Knowledge & 90,60 & 6,51 & $80-100$ \\
\hline Attitudes & 33,92 & 2,23 & $27-38$ \\
\hline
\end{tabular}

The mean score of knowledge after the implementation of education was 90.60 while the mean score for attitude was 33.92

\section{c. Analysis Bivariate:}

Table 6. Analysis of differences in Knowledge and Attitudes Before and After the Implementation of the Hatam Language Booklet

\begin{tabular}{|l|l|c|c|c|c|c|}
\hline Variable & Measurement & $\mathbf{n}$ & Mean & Enhancement & SD & $\boldsymbol{p}$-Value \\
\hline \multirow{2}{*}{ Knowledge } & Before & 50 & 50,80 & \multirow{2}{*}{39,80} & 14,18 & \multirow{2}{*}{0,000} \\
& After & 50 & 90,60 & & 6,51 & 2,23 \\
\hline \multirow{2}{*}{ Attitudes } & Before & 50 & 26,94 & \multirow{2}{*}{6,98} & 22,0 & 0,000 \\
& After & 50 & 33,92 & & \\
\hline
\end{tabular}

The mean score of knowledge before and after the implementation of the Hatam Language Education Booklet has increased by 39.80 and family attitudes have increased by 6.98 . The results of further analysis obtained the p-value of 0.000 , which means that there is a significant difference in the average score of family knowledge and attitudes before and after being given the Hatam language education booklet.

\section{Discussion}

Characteristics of respondents in this study include age, gender, occupation and education. Respondents in this study were families who have toddlers and one of their family members was diagnosed with positive pulmonary tuberculosis with an age between 20 to 55 years, all respondents were women and most of them did not have occupation, the respondents had the most education level with basic education level and the lowest with the lowest level of education. middle education.

Differences in knowledge and attitudes of families before and after the application of the Education Booklet. Knowledge
Based on the results of the statistical test, it shows that there is a significant increase in the mean score of knowledge before and after education. One of the efforts to deal with pulmonary tuberculosis is health promotion to increase public knowledge using various method, health education through the media, because the media makes it easier to receive health messages for the public or people with pulmonary tuberculosis 6

This research is in accordance with other research conducted on the island of Madura by using a pictorial pocket book in Madura language which shows an increase in knowledge for patients with pulmonary tuberculosis and supervisors taking medication ${ }^{8}$. Another study was also carried out in nine cities in India by Hudart et al which assessed how knowledge about tuberculosis and preventive behavior during Tuberculosis treatment, the results of the study were that knowledge, education, and equality of language used increase knowledge and adherence to preventive behavior. infection.

In general, knowledge and attitudes regarding Tuberculosis vary across countries from an understanding 
of the causes of infection to the belief that it is the evil eye, and from a supportive viewpoint of stigma against the disease and patients. Adequate knowledge and positive attitudes about tuberculosis patients greatly contribute to improving health service seeking behavior ${ }^{5}$ Knowledge, individual attitudes of the family and society depend on the actualized patterns of the family, the level of individual maturity and development, the knowledge obtained, the health and culture of the local community. Researchers argue that by taking a cultural approach by providing education and information about pulmonary tuberculosis in children can increase knowledge and positive attitudes and medication adherence to patients ${ }^{2}$.

Attitudes: Based on the results of the statistical test, it shows that there is a significant increase in the mean score of attitudes before and after education. Attitude is a mental and neural condition, which is obtained from experiences that direct and dynamically influence individual responses to all related objects and situations, attitudes have cognitive, affective, and conative components $^{11,12}$. In Ethiopia shows the importance of health education interventions to increase knowledge and awareness and positive attitudes to prevent and control tuberculosis. The positive or negative attitude of society towards Tuberculosis is shaped by educational, knowledge and social status. According to the researchers' assumptions, a positive attitude is formed from good knowledge and to be able to use method or ways to provide education is important to increase knowledge and attitudes about Tuberculosis ${ }^{13-22}$.

\section{Conclusion}

1. Respondents in this study were families who have children under five and family members diagnosed with tuberculosis with an average age of 37.42 , the lowest was 20 years and the highest was 50 years. Respondents have the highest level of education with basic education level and the lowest with secondary education, all respondents are female and most of them do not work.

2. The family knowledge and attitudes score was lower before the implementation of the Hatam language book when compared to after the implementation of Education

Ethical Clearance: Taken from Poltekkes Kemenkes Sorong ethical committee

Source of Funding: Poltekkes Kemenkes Sorong

\section{Conflict of Interest: Nil}

\section{References}

1. Bisallah, C.I., Rampai,L., Munn-SannLye., Sidik,S.M., Ibrahim, N., Illyasu, Z., \& Onyillo,M.O. Effectiveness of health education intervention in improving knowledge, attitude and practices regarding tuberculosis among HIV patients in General Hospital Minna, Nigeria A randomized control trial. 2018; 13 (2)e0192276 https://doi.org/ http://doi.org/10.1371/journal.pone.0192276

2. Datiko, D.G., Habte,D., Jerene,D \& Suarez,P. Knowledge, attitudes, and Practices related to TB among the general population of Ethiopia: Findings frpm a national cross-sectinonal survey. Journal Plos One, 2019; 14(10): 1-16. https://doi.org/http:// doi.org/10.1371/journal.pone.0224196

3. Ditjen P2PL, K. Buku-Petunjuk-TeknisManajemen-dan-Tatalaksana-TB-Anak.pdf. Kementerian Kesehatan RI. 2016.

4. Faradis.N.A., \& I. . Implementasi Kebijakan Permenkes Nomor 67 Tahun 2016 Tentang Penanggulangan Tuberculosis. HIGEIA JOURNAL OF PUBLIC HEALTH RESEARCH AND DEVELOPMENT, 2018; 2(1), 307-319. Retrieved from http://journal.unnes.ac.id/sju/index. php/higeia

5. Hudart,S.H, Bossuroy, T., Pons, V., Baral, S., Pai, M., \& Delavallade, C. (Knowledge about tuberculosis and infection prevention behavior : A nine city longitudinal study from India. Journal Plos One, 2018; 1-15. https://doi.org/http://doi. org/10.1371/journalpone.

6. Kementerian Kesehatan RI. Infodatin Pusat Data dan Informasi Tuberkulosis. InfoDATIN. https:// doi.org/2442-7659. 2018.

7. Kigozi, N. G., Heunis, J. C., Engelbrecht, M. C., Rensburg, A. P. J. Van, \& Rensburg, H. C. J. D. Van. Tuberculosis knowledge, attitudes and practices of patients at primary health care facilities in a South African metropolitan : research towards improved health education. BMC Public Heath, 2017; 1-8. https://doi.org/10.1186/s12889-017-4825-3

8. Maghfiroh, L., Nugraha, A., Pratama, W., \& Rachmawati, E. Pengaruh Pemberian Edukasi Menggunakan Buku Saku Bergambardan Berbahasa Madura terhadap Tingkat Pengetahuan Penderita dan Pengawas Menelan Obat Tuberkulosis Paru 
(The Effect of A Pictorial Booklet with Madurese Language on Level of Knowledge among Tuber, 2017; 5(3), 420-424..

9. Pramita.E. Masyarakat diminta partisipatif aktif penanggulangan TB, 2017.

10. Unicef. ENDING TUBERCULOSIS IN CHILDREN. 2016.

11. Wawan, A \& Dewi. Teori dan pengukuran pengetahuan, sikap dan perilaku manusia. Yogyakarta: Nuha Medika. 2016

12. WHO, Unicef, T. G. F. Roadmap towards ending TB in children and adolescents (Second). Switzerland: WHO. 2018.

13. Mallongi, A., Indra, R., Arief, M.U., Fais Satrianegara, M., Environmental pollution and health problems due to forest fires with $\mathrm{CO}_{2}$ parameters., Medico-Legal Update Volume 20, Issue 3, July-September 2020, Pages 888-892.

14. Mallongi, A., Puspitasari, A., Ikhtiar, M.,Arman, Arsunan, A.A., Analysis of risk on the incidence of scabies Personal Hygiene in Boarding School Darul Arqam Gombara Makassar., Indian Journal of Public Health Research and Development., Volume 9, Issue 4, April 2018, Pages 227-231

15. Masriadi, Azis, R.,Sumantri, E., Mallongi, A., Effectiveness of non pharmacologic therapy through surveillance approach to blood pressure degradation in primary hypertension patients, Indonesia., Indian Journal of Public Health Research and Development. Volume 9, Issue 4, April 2018, Pages 249-255

16. Posmaningsih, D.A., Aryasih, G.A.M., Hadi, M.C., Marwati, N.M., Mallongi, A. The influence of media booklet in behavior change of waste management in elementary school students, South Denpasar, Bali., Indian Journal of Public Health
Research and Development. Volume 9, Issue 8, August 2018, Pages 1506-1511

17. Mallongi, A., Parkpian, P., Pataranawat, P., Chinwetkitvanich, S ., Mercury distribution and its potential environmental and health risks in aquatic habitat at artisanal buladu gold mine in Gorontalo Province, Indonesia, Pakistan Journal of Nutrition Volume 14, Issue 12, 2015, Pages 1010-1025

18. A Mallongi, D Safiu, H Amqaim, A Syam, M Hatta, T Sutarti, A Muhith,. Modelling of S02 and CO Pollution Due to Industry PLTD Emission Tello in Makassar Indonesia. Journal of Engineering and Applied Sciences 14 (2), 634-640

19. Mallongi, A., Daud, A., Ishak, H., La Ane, R., Birawida, A.B., Ibrahim, E., Selomo, M., Rahman, S.A. Clean water treatment technology with an upflow slow sand filtration system from a well water source in the tallo district of Makassar. Journal of Environmental Science and Technology, 2017; Volume 10, Issue 1, Pages 44-48

20. Hasmi, Mallongi, A. Health risk analysis of lead exposure from fish consumption among communities along Youtefa Gulf, Jayapura. Pakistan Journal of Nutrition 2016; Volume 15, Issue 10, 15 September Pages 929-935

21. M N Massi' S Wahyuni, H Halik, Anita, I Yusuf, F J Leong, T Dick, S Phyu ., Drug resistance among tuberculosis patients attending diagnostic and treatment centres in Makassar, Indonesia., Int J Tuberc Lung Dis. 2011 Apr;15(4):489-95. doi: 10.5588/ijtld.09.0730.

22. Kayame, R., Mallongi, A. Relationships between smoking habits and the hypertension occurrence among the adults of communities in paniai regency, Papua Indonesia. Indian Journal of Public Health Research and Development 2018; Volume 9, Issue 1, Pages 332-336 